\title{
ANALISIS KINERJA ASET DESA DARI PERSPEKTIF KERANGKA MANAJEMEN ASET PUBLIK (STUDI KASUS DESA LABRUK LOR, KECAMATAN LUMAJANG, KABUPATEN LUMAJANG)
}

\author{
Farchan Maulana ${ }^{1}$, \\ Direktorat Jenderal Perbendaharaan, Kementerian Keuangan \\ Intan Puspitarini2* \\ Politeknik Keuangan Negara (PKN) STAN
}

\begin{abstract}
This study aims to analyze the performance of village assets, by taking a case study of Labruk Lor Village, Lumajang Regency, East Java Province. Measurement of asset performance as part of the evaluation of asset management provides parameters for the village government to determine whether an asset has been used/utilized optimally. With the stipulation of the village as one of the subjects of development in 2 (two) consecutive RPJMN, namely the 2015-2019 RPJMN and 2020-2024 RPJMN, enhancement of both quality and quantity of village assets is becoming unavoidable. The research method used in this study is descriptive qualitative that is conducted through interviews, field observations and literature research. Respondents, selected using a purposive sampling method, are village officials, village asset users, policy makers, as well as village officials. This research is based on 2 (two) Basic Indicators, namely inventory and information on village assets and 4 (four) Progressive Indicators, namely Physical Condition, Asset Use, Utilization and Financial. The results showed that the asset performance of Labruk Lor village obtained a value of 0.636 (enough) for Basic Performance, and an average of 0.785 (good) for Advanced Performance.
\end{abstract}

Keywords: asset management, performance measurement, public assets, village, , village aset

\begin{abstract}
ABSTRAK
Penelitian ini bertujuan untuk melakukan analisis kinerja aset desa, dengan mengambil studi kasus Desa Labruk Lor, Kabupaten Lumajang, Provinsi Jawa Timur. Pengukuran kinerja aset sebagai bagian dari evaluasi pengelolaan aset memberikan parameter bagi pemerintah desa untuk mengetahui apakah suatu aset telah digunakan/didayagunakan dengan optimal. Dengan ditetapkannya desa sebagai salah satu subyek pembangunan dalam 2 (dua) RPJMN berturutturut, yaitu RPJMN 2015-2019 dan RPJMN 2020-2024, maka peningkatan kualitas dan kuantitas aset atau kekayaan desa menjadi hal yang tidak bisa dihindari. Metode penelitian bersifat kualitatif deskriptif melalui teknik wawancara, observasi lapangan dan penelitian dokumen. Narasumber dipilih dengan menggunakan metode purposive sampling, yaitu terhadap perangkat desa, pemanfaat aset desa, penyusun kebijakan pengelolaan pengukuran kinerja aset publik, serta pejabat pengelola aset desa. Analisis kinerja aset desa dalam riset ini didasarkan pada 2 (dua) Indikator Dasar, yaitu inventarisasi dan informasi aset desa dan 4 (empat) Indikator Lanjutan, yaitu kondisi fisik, penggunaan, pemanfaatan dan finansial. Hasil penelitian menunjukkan bahwa kinerja aset desa Labruk Lor memperoleh nilai 0,636 (cukup) untuk kinerja dasar, dan rerata 0,785 (baik) untuk kinerja lanjutan.
\end{abstract}

Kata kunci: pengukuran kinerja, kinerja, aset publik, aset desa, pengelolaan aset Klasifikasi JEL: R5; H110

\section{PENDAHULUAN}

\footnotetext{
2 *Politeknik Keuangan Negara STAN, Kementerian Keuangan, Jl. Bintaro Utama, Sektor V, Tangerang Selatan, 085810151834, intan.puspitarini@pknstan.ac.id.
} 


\section{8 | Bina Ekonomi}

Pengukuran kinerja aset publik merupakan satu kegiatan yang dilakukan oleh entitas Pemerintah untuk mengukur seberapa optimal suatu aset telah digunakan/didayagunakan dan untuk mengevaluasi apakah pengelolaan aset yang dimiliki telah dilaksanakan dengan baik. Ketidakoptimalan penggunaan/pendayagunaan aset publik menimbulkan biaya-biaya ekstra yang menjadi beban negara, seperti biaya pemeliharaan, biaya penyimpanan, hingga biaya peluang yang seringkali tidak disadari oleh Pemerintah. Upaya untuk mendayagunakan aset yang tidak optimal penggunaannya atau bahkan menganggur (idle) telah banyak dilakukan Pemerintah Pusat, sebagaimana dilakukan terhadap Barang Milik Negara (BMN) eks Kantor BPKP Cirebon di Jalan Dr. Wahidin Sudiro Husodo, Cirebon, aset berupa 106 unit apartemen di Jalan Casablanca, Jakarta Pusat, aset tanah dan bangunan eks-kelolaan PT PPA di Kabupaten Klungkung (DJKN, 2020). Upaya ini selain ditujukan untuk memaksimalkan pelayanan kepada masyarakat, efisiensi APBN, mengoptimalkan penggunaan aset, juga diharapkan dapat meningkatkan pendapatan negara (DJKN, 2021).

Upaya pendayagunaan aset dapat dilakukan hanya setelah entitas tersebut mengetahui kinerja yang telah dicapai suatu aset. Setelah suatu aset diperoleh, aset mulai "bekerja" sesuai dengan tujuan yang ditetapkan saat perencanaannya. Dalam perjalanannya, kinerja aset seringkali tidak maksimal atau tidak sesuai dengan perencanaannya, yang diantaranya bisa disebabkan oleh adanya perubahan struktur organisasi, perubahan peruntukan aset, hingga perubahan kondisi aset. Kondisi ketidakoptimalan ini seringkali tidak disadari oleh entitas karena terjadi secara perlahan dan/atau karena kesibukan lain yang dihadapi entitas. Hal ini dapat dihindari jika entitas mempunyai perangkat untuk mengukur kinerja aset.

Kaganova dan Nayyar-Stone (2000) menyimpulkan bahwa aset negara yang dimiliki oleh pemerintah daerah di hampir semua negara memiliki nilai yang besar namun belum dikelola secara optimal. Lebih lanjut, The Center for Indonesian Policy Studies (CIPS) (2019) melalui publikasinya menyampaikan bahwa masih banyak masalah yang terjadi pada praktik pengelolaan aset desa, terutama pemanfaatan aset desa berupa tanah. Kewenangan skala lokal desa cenderung dapat disalahgunakan oleh oknum pengelola aset desa itu sendiri. United Nations Development Program (2018) menggarisbawahi bahwa sistem pelaporan dan evaluasi menjadi bagian dari sistem pengelolaan aset yang baik. Dengan kata lain, kinerja aset publik harus diukur secara berkala, apakah aset tersebut telah digunakan sesuai dengan tujuan pengadaannya dan/atau didayagunakan secara optimal. Studi literatur yang dilakukan penulis terhadap kerangka pengelolaan aset publik di negara Australia, Selandia Baru, Inggris dan Kanada menyimpulkan bahwa sistem pengelolaan aset publik pada negara-negara tersebut menekankan pentingnya kegiatan evaluasi kinerja aset, di samping kegiatan pelaporan dan monitoring.

Penelitian mengenai pentingnya pengukuran kinerja aset publik telah dilakukan baik dalam lingkup Indonesia maupun internasional. Jooste (2003) dalam salah satu penelitiannya menyatakan bahwa pengukuran kinerja merupakan bagian penting dari pengelolaan aset publik. Kaganova dan Telgarsky (2018) menambahkan pentingnya evaluasi atas pengelolaan aset publik agar pemerintah memahami apa yang harus diperbaiki dan bagaimana caranya melalui evaluasi atas kinerja atas pengelolaan aset dan kinerja dari aset itu sendiri. Hanis et al (2011) menyampaikan bahwa salah satu kekurangan yang ada dalam pengelolaan aset publik di Indonesia adalah absennya aturan dan perangkat yang digunakan dalam evaluasi pengelolaan aset publik. Puspitarini et al (2019) juga mengatakan bahwa keberadaan perangkat dan parameter dalam mengukur kinerja merupakan salah satu isu penting dalam pengukuran kinerja aset publik.

Beberapa penelitian terdahulu menawarkan parameter untuk mengukur kinerja aset untuk entitas pemerintahan di tingkat Pusat maupun Daerah, diantaranya penelitian yang dilakukan oleh Setiyono (2018), Hariyono (2007), Haas (2003), Hwang (2018), Puspitarini (2019) dan Riratanaphong (2015). Dari sisi regulasi, Pemerintah Pusat juga telah memiliki perangkat 
pengukuran kinerja BMN, yaitu melalui Keputusan Kementerian Keuangan (KMK) Nomor 349 Tahun 2018 tentang Tata Cara Pelaksanaan Evaluasi Kinerja Barang Milik Negara. Literatur review yang dilakukan penulis menunjukkan bahwa belum terdapat regulasi maupun penelitian mengenai bagaimana mengukur kinerja aset desa. Penelitian terdahulu dan regulasi yang terbit lebih ditujukan untuk entitas publik di tingkat Pemerintah Pusat dan Daerah, yang secara umum memiliki aset dengan kompleksitas tinggi, sehingga tidak bisa diadopsi langsung untuk mengukur kinerja aset desa.

Undang-Undang Nomor 6 Tahun 2014 tentang Desa memberikan kewenangan kepada desa untuk mengatur dan mengurus kepentingan masyarakat berdasarkan hak asal usul, adat istiadat, dan nilai sosial budaya masyarakat desa secara mandiri, termasuk di dalamnya pengelolaan keuangan dan aset desa. Dengan ditetapkannya desa sebagai salah satu subyek pembangunan dalam 2 (dua) RPJMN berturut-turut, yaitu RPJMN 2015-2019 dan RPJMN 20202024, maka peningkatan kualitas dan kuantitas aset atau kekayaan desa menjadi hal yang tidak bisa dihindari. Aset desa merupakan salah satu motor penggerak dalam menghasilkan pendapatan desa. Oleh karena itu, kinerja aset desa menjadi satu hal yang harus terus dievaluasi untuk memastikan bahwa setiap aset telah digunakan dan/atau dimanfaatkan secara optimal sehingga mampu berkontribusi terhadap pendapatan desa.

Desa, merupakan entitas pemerintahan dengan karakteristik yang jauh lebih sederhana dibandingkan entitas Pemerintah Pusat dan Daerah. Aset yang dimiliki desa pun tidak sebanyak dan sekompleks aset yang dimiliki Pemerintah Pusat dan Daerah. Dalam pengukuran kinerja aset, desa tentu memerlukan indikator pengukuran yang lebih sederhana. Berdasarkan studi literatur yang dilakukan peneliti, bagaimana mengukur kinerja aset desa belum pernah atau masih jarang dilakukan. Maka yang menjadi permasalahan dalam penelitian ini adalah bagaimana melakukan pengukuran kinerja aset desa dan bagaimana jika pengukuran tersebut diterapkan di satu desa yang menjadi contoh studi kasus.

Penelitian ini mengambil studi kasus di Desa Labruk Lor, Kecamatan Lumajang, Kabupaten Lumajang, Propinsi Jawa Timur dengan pertimbangan bahwa desa tersebut memiliki beragam jenis aset dengan pencatatan serta registrasi aset yang relatif bagus. Di samping itu berdasarkan Indeks Desa Membangun (IDM) yang dirilis oleh Kemendes PDTT, dari lima desa di wilayah Kecamatan Lumajang, hanya Desa Labruk Lor yang mampu meraih predikat Desa Mandiri, sedangkan 4 (empat) desa yang lain baru mencapai kategori Desa Berkembang (Desa Banjarwaru, Desa Blukon, Desa Boreng dan Desa Denok).

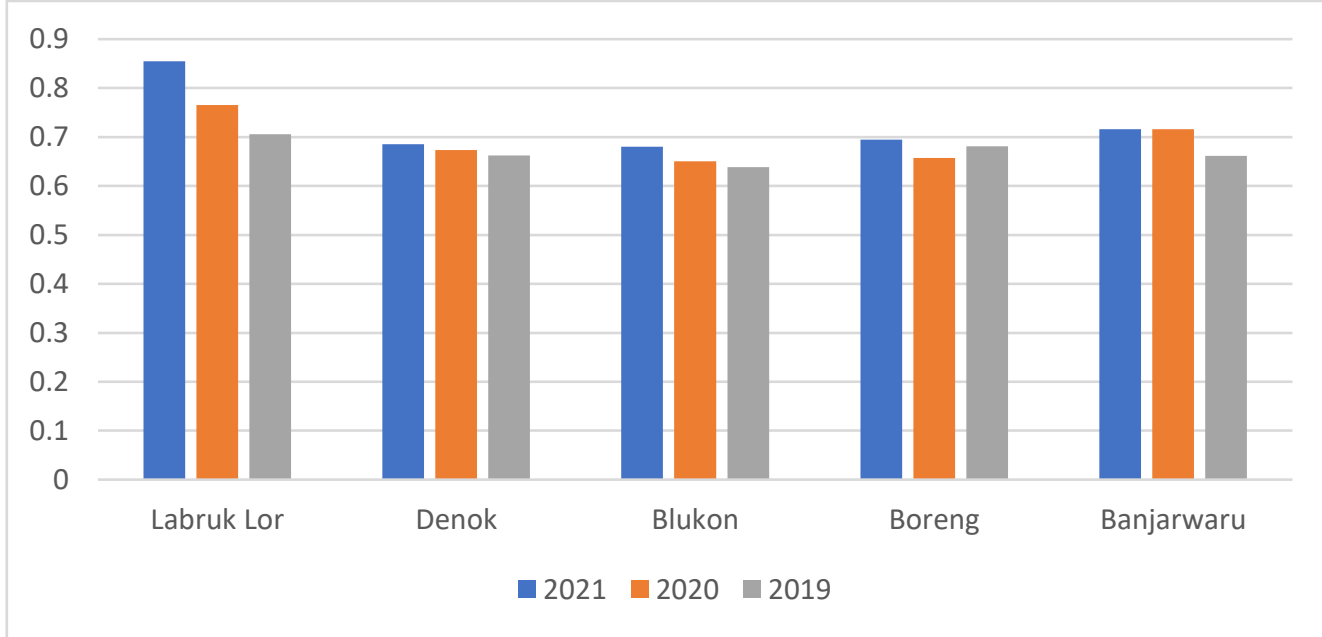

Gambar 1.1 IDM Desa di Kecamatan Lumajang 2019-2021 https://idm.kemendesa.go.id/status 


\section{METODE DAN DATA}

Penelitian ini dilakukan dengan metode kualitatif deskriptif, yaitu dengan mengukur kinerja aset Desa Labruk Lor dengan menggunakan parameter-parameter pengukuran yang digunakan oleh Kaganova (2018) dan Hariyono (2007). Parameter yang ditawarkan Kaganova (2018) dipilih dalam penelitian ini dengan mempertimbangkan kesederhanaan dan kemudahan dalam pengaplikasiannya, sehingga lebih kompatibel untuk pengukuran kinerja aset pada tingkat desa. Pengukuran kinerja aset di sektor publik oleh Kaganova (2018) menitikberatkan pada aspek inventarisasi dasar dan keterbukaan informasi kepada pemangku kepentingan dan masyarakat secara umum. Parameter ini selanjutnya menjadi Indikator Dasar pengukuran kinerja aset desa. Indikator Dasar belum mampu menangkap kinerja aset dari aspek optimalisasi penggunaan aset, yaitu bagaimana aset difungsikan dalam penggunaan sehari-hari dan apakah aset mampu memberikan kontribusi finansial kepada pemilik. Lebih lanjut, Indikator Dasar juga belum mempertimbangkan kondisi fisik aset, yang sangat berpengaruh terhadap kinerja aset. Untuk itu, penelitian ini mengombinasikan dengan parameter lain dari Hariyono (2007), yang terdiri dari empat parameter yaitu kondisi fisik, penggunaan/fungsionalitas, pemanfaatan/utilisasi dan kinerja finansial aset. Parameter ini selanjutnya menjadi Indikator Lanjutan pengukuran kinerja aset desa.

Dalam penelitian ini, jenis data yang digunakan adalah data primer dan data sekunder. Data primer didapatkan dari wawancara dengan para informan. Data sekunder didapatkan dari data dokumen kepustakaan seperti peraturan perundang-undangan, laporan pengelolaan keuangan dan aset desa, kajian penelitian dan dokumen lain yang terkait dengan pengelolaan aset dan pengukuran kinerja aset desa.

Teknik yang diterapkan dalam pengumpulan data dalam penelitian ini, yaitu:

a. Wawancara mendalam (in-depth interview) adalah suatu cara untuk mendapatkan informasi dengan cara memberikan pertanyaan secara langsung kepada responden yang dapat memberikan informasi yang lengkap dan komprehensif terkait dengan penelitian.

1) Informan pada penelitian ini dipilih menggunakan metode purposive sampling. Sugiyono $(2019 ; 289)$ menyatakan bahwa purposive sampling adalah teknik pengambilan sampel sumber data dengan pertimbangan tertentu, yang dalam kaitan ini adalah tanggung jawab dalam pengelolaan aset, posisi jabatan yang diemban, hingga durasi waktu petugas/pejabat yang bersangkutan dalam mengemban tanggung jawab dan jabatan.

2) Wawancara dilakukan kepada Perangkat Desa Labruk Lor (Kepala Desa, Sekretaris Desa, Kepala Urusan Tata Usaha dan Umum, Kepala Urusan Keuangan, Kepala Urusan Perencanaan); Pihak Pemanfaat Aset Desa (Kepala PAUD Amanah Desa Labruk Lor, Bidan dan Perawat Desa Labruk Lor, Pegiat Kesenian Tari Desa Labruk Lor, serta Warga Desa Labruk Lor); Kepala Seksi Pengelolaan BMN KPKNL Jakarta II, Ditjen Kekayaan Negara, Kementerian Keuangan, pakar dalam pengukuran kinerja aset publik; Kepala Bidang Bina Pemerintahan Desa Dinas Pemberdayaan Masyarakat Desa Kab. Lumajang; dan Kementerian Dalam Negeri (Plt. Kasubdit Fasilitasi Pengelolaan Aset Desa, Kepala Seksi Pemanfaatan Aset Desa).

3) Pertanyaan dikembangkan berdasarkan rumusan masalah, namun tetap dengan berpedoman pada parameter yang dikembangkan oleh Kaganova (2018) dan Hariyono (2007).

b. Dokumentasi adalah setiap bahan tertulis dalam bentuk karangan, memo, pengumuman, petunjuk, majalah, buletin, pernyataan, aturan lembaga masyarakat, dan siaran berita ke media massa. Dari uraian di atas, metode dokumentasi adalah pengumpulan data dengan cara menelaah catatan-catatan penting yang sangat berkaitan erat dengan objek penelitian. 
c. Tinjauan Literatur. Merupakan kumpulan referensi buku, artikel, jurnal, hasil penelitian yang memiliki relevansi dengan pendekatan teoritis yang digunakan dalam penelitian.

Data yang dikumpulkan dari wawancara, observasi dan penelitian dokumen kemudian diproses terlebih dahulu dengan melakukan konversi menjadi data teks sehingga tidak memerlukan kaidah perhitungan statistik ataupun matematik. Penelitian ini menggunakan teknik analisis data Model Miles and Huberman yaitu dengan menganalisa data kualitatif secara interaktif dan berlangsung secara terus menerus sampai tuntas, sehingga datanya menjadi jenuh. Aktivitas dalam analisis data diantaranya adalah data reduction, data display dan conclusion drawing/verification.

Penulis melakukan koding dengan referensi yang ditulis oleh Mahpur (2010) agar informasi yang diperoleh tajam dan akurat. Urutan langkah koding yang telah dilakukan diantaranya adalah menyiapkan data mentah berupa rekaman wawancara dan rekaman video yang kemudian ditranskrip menjadi verbatim, pemadatan fakta, menyiapkan probing untuk pendalaman data, pengumpulan fakta sejenis, menentukan kategori, dan membangun konsep serta menarasikan. Untuk menguji kredibilitas data, peneliti melakukan triangulasi sumber yaitu dengan mengecek data melalui beberapa sumber. Sumber-sumber tersebut terdiri dari hasil wawancara, dokumentasi, dan penelaahan sumber lainnya.

\section{PEMBAHASAN}

\section{a. Kondisi Pengelolaan Aset Desa}

Aset desa meliputi kekayaan asli desa, dibeli atau diperoleh atas beban APBDesa, hibah dan sumbangan atau yang sejenis, sebagai pelaksanaan dari perjanjian/kontrak dan/atau ketentuan peraturan undang-undang, hasil kerja sama desa, dan yang berasal dari perolehan lain yang sah. Desa Labruk Lor merupakan salah satu dari lima desa yang berada di wilayah administrasi Kecamatan Lumajang, dipimpin oleh seorang Kepala Desa, dibantu oleh seorang Sekretaris Desa dan sembilan orang perangkat desa, yang terdiri dari Kepala Seksi, Kepala Urusan dan Kepala Dusun.

Berikut adalah data aset desa di wilayah Desa Labruk Lor, Kecamatan Lumajang hingga tanggal 31 Desember 2020:

Tabel 2.1 Daftar Aset Desa Labruk Lor s.d. 2020

\begin{tabular}{|c|l|c|c|c|c|}
\hline No & \multicolumn{1}{|c|}{ Aset Desa } & $\begin{array}{c}\text { Tahun } \\
\text { Perolehan }\end{array}$ & $\begin{array}{c}\text { Identitas } \\
\text { Barang }\end{array}$ & $\begin{array}{c}\text { Jumlah } \\
\text { Barang } \\
\text { Volume }\end{array}$ & $\begin{array}{c}\text { Sumber } \\
\text { Dana }\end{array}$ \\
\hline 1 & Tanah Kas Desa TKD & 1970 & & $\begin{array}{c}101.660 \\
\mathrm{~m}^{2}\end{array}$ & - \\
\hline 2 & Kantor Balai Desa & 1970 & & $876 \mathrm{~m}^{2}$ & - \\
\hline 3 & Ponkesdes, R.PKK dan Ruang Kasun & 2016 & & 1 Unit & ADD \\
\hline 4 & $\begin{array}{l}\text { R.Kepala Desa, R. Sekdesa, } \\
\text { R.Keuangan, R.Pendamping }\end{array}$ & 2017 & & 1 Unit & ADD \\
\hline 5 & R.Pelayanan dan R.Kaur & 2018 & & 1 Unit & ADD \\
\hline 6 & Gedung Paud & 2013 & & 1 Unit & P2KP \\
\hline 7 & Gedung Posyandu Balai Desa & 2015 & & 1 Unit & ADD \\
\hline 8 & Musholah Balai Desa dan Parkiran & 2013 & & 1 Unit & ADD \\
\hline 9 & Kamar Mandi Kantor Desa & 2012 & & 1 Unit & ADD \\
\hline 10 & $\begin{array}{l}\text { Kendaraan Operasional Kades } \\
\text { Megapro }\end{array}$ & 2010 & N 3502 \\
YP & 1 Unit & Hibah \\
\hline
\end{tabular}




\begin{tabular}{|c|l|c|c|c|c|}
11 & Kendaraan Operasional Sekdes WIN & 1990 & $\begin{array}{c}\text { N 9844 } \\
\text { WA }\end{array}$ & 1 Unit & Hibah \\
\hline 12 & Kendaraan Operasional BPD & 1990 & $\begin{array}{c}\text { N 9877 } \\
\text { WB }\end{array}$ & 1 Unit & Hibah \\
\hline 13 & Ambulan Desa & 2017 & $\begin{array}{c}\text { N 1005 } \\
\text { YP }\end{array}$ & 1 Unit & Hibah \\
\hline 14 & Laptop & $\begin{array}{c}2014- \\
2018\end{array}$ & & 4 unit & BHP/ADD \\
\hline 15 & Komputer & $\begin{array}{c}2014- \\
2018\end{array}$ & & 6 unit & BHP/ADD \\
\hline 16 & Printer & $\begin{array}{c}2014- \\
2018\end{array}$ & & 6 unit & BHP/ADD \\
\hline
\end{tabular}

Sumber: Catatan Inventaris Desa, diolah Penulis

\section{b. Kebijakan Umum Pengukuran Kinerja Aset Publik}

Pakar pengukuran kinerja aset publik, HA (wawancara, 13 Juni 2020), menyampaikan bahwa saat ini Kementerian Keuangan telah melaksanakan tahapan piloting pengukuran kinerja aset pemerintah pusat (Barang Milik Negara) yang mempunyai nilai signifikan, yaitu BMN tanah dan bangunan. Pengelolaan aset publik pada masa pandemi saat ini membutuhkan fleksibilitas tinggi, dimana penggunaan aset publik dimungkinkan untuk berubah fungsi seperti wisma atlet yang difungsikan menjadi Rumah Sakit Rujukan COVID-19. Hal yang perlu ditekankan adalah, meskipun menggunakan instrumen yang sederhana, pengukuran kinerja harus mampu memberikan gambaran kepada pengelola aset apakah sebuah aset benar-benar berfungsi dan dimanfaatkan sesuai dengan intensi pengelola.

GU dan PU (wawancara, 22 Juni 2020) menyatakan bahwa penyusunan Permendagri Nomor 1 Tahun 2016 yang menjadi dasar hukum pengelolaan aset desa diadopsi dari Peraturan Pemerintah Nomor 27 Tahun 2014 tentang Pengelolaan Barang Milik Negara/Daerah. Permendagri tersebut bercermin dari praktik pengelolaan BMN yang dilakukan oleh Kementerian Keuangan. Pada tataran penerapannya, secara umum masih banyak Pemerintah Desa yang saat ini belum mengaplikasikan peraturan tersebut. Sebagai contoh, terdapat desa yang belum melakukan pencatatan inventaris sebagai dasar pengelolaan asetnya.

Belum sampainya informasi terkait dengan regulasi ini kepada pihak pemerintah kabupaten atau desa diakui menjadi kendala dalam aplikasi regulasi ini. Faktor volatilitas pegawai (mutasi dan perpindahan jobdesc) yang telah dilakukan sosialisasi ikut menjadi penghambat. Selain itu juga terdapat faktor lambannya pemerintah kabupaten dalam menerbitkan regulasi pelaksana dalam peraturan daerah masing-masing terkait dengan pengelolaan aset desa. Terakhir, regulasi ini akan segera dilakukan revisi sehingga sosialisasinya dihentikan oleh pihak Kementerian Dalam Negeri.

AR (wawancara, 9 Juni 2020) menambahkan kondisi pengelolaan aset desa yang ada di Kabupaten Lumajang secara umum dapat dikatakan belum optimal. Terdapat masalah seperti legalitas aset berupa bukti kepemilikan Tanah Kas Desa (TKD) hingga penyalahgunaan wewenang kepala desa dalam mengelola aset desa.

\section{c. Pengukuran Kinerja Dasar Aset Desa Labruk Lor}

Indikator Dasar mengadopsi metode yang dikembangkan oleh Kaganova (2018), yang terdiri dari 2 (dua) indikator, yaitu inventarisasi dan keterbukaan informasi. 2 indikator tersebut diturunkan menjadi poin wawancara kepada narasumber, yang selanjutnya diberikan score untuk 
menilai seberapa baik atau buruk pengelolaan aset publik yang telah dijalankan. Berikut adalah hasil evaluasi Kinerja Dasar Aset Desa Labruk Lor:

Tabel 3.1 Hasil Evaluasi Kinerja Dasar Aset Desa Labruk Lor, Kab. Lumajang, Jawa Timur

\begin{tabular}{|c|c|c|c|}
\hline $\begin{array}{c}\text { Parameter } \\
\text { Pengukuran }\end{array}$ & Poin Wawancara & Hasil & Poin \\
\hline \multirow[t]{6}{*}{$\begin{array}{l}\text { Inventarisasi } \\
\text { aset dasar }\end{array}$} & $\begin{array}{l}\text { Proses inventarisasi aset } \\
\text { yang telah dilakukan. }\end{array}$ & $\begin{array}{l}\text { Proses inventarisasi dan tindak } \\
\text { lanjut input data hasil } \\
\text { inventarisasi telah dilakukan. }\end{array}$ & 0,80 \\
\hline & $\begin{array}{l}\text { Progress tindak lanjut } \\
\text { inventarisasi aset. }\end{array}$ & $\begin{array}{l}\text { Pemutakhiran data sempat } \\
\text { terhenti pada tahun 2018/2019 } \\
\text { kemudian dimutakhirkan } \\
\text { kembali pada tahun } 2020 \text {. }\end{array}$ & 0,60 \\
\hline & $\begin{array}{l}\text { Proses komputerisasi hasil } \\
\text { inventarisasi aset }\end{array}$ & $\begin{array}{l}\text { Komputerisasi hasil } \\
\text { inventarisasi aset dilakukan } \\
\text { secara semi manual }\end{array}$ & 0,70 \\
\hline & $\begin{array}{l}\text { Penggunaan informasi yang } \\
\text { diperoleh dari inventarisasi } \\
\text { aset. }\end{array}$ & $\begin{array}{l}\text { a. Pembubuhan label aset } \\
\text { atau plang penanda dibuat } \\
\text { secara manual, namun justru } \\
\text { aset terbesar, yakni TKD, belum } \\
\text { diberi tanda plang. } \\
\text { b. Informasi atas } \\
\text { inventarisasi aset cenderung } \\
\text { kurang dimanfaatkan dalam } \\
\text { rangka pengelolaan aset } \\
\text { (rencana pengadaan baru } \\
\text { dan/atau pemeliharaan aset } \\
\text { yang ada). }\end{array}$ & 0,50 \\
\hline & $\begin{array}{l}\text { Bagaimana informasi } \\
\text { klasifikasi atas aset yang } \\
\text { dimiliki? }\end{array}$ & $\begin{array}{l}\text { Pengelola aset desa belum } \\
\text { melakukan klasifikasi atas aset } \\
\text { yang dikelola }\end{array}$ & 0,40 \\
\hline & $\begin{array}{l}\text { Bagaimana ketersediaan } \\
\text { akan regulasi terkait dengan } \\
\text { penggunaan harga pasar } \\
\text { sebelum keputusan adanya } \\
\text { pengadaan/sewa/jual/hapus } \\
\text { aset? }\end{array}$ & $\begin{array}{l}\text { a. Ketersediaan regulasi } \\
\text { harga pasar untuk pengadaan/ } \\
\text { sewa/jual/hapus aset } \\
\text { diupayakan oleh pihak } \\
\text { pemerintah Desa Labruk Lor dan } \\
\text { upaya tersebut selalu comply } \\
\text { dengan regulasi yang berlaku } \\
\text { dalam rangka pengadaan. }\end{array}$ & 0,60 \\
\hline
\end{tabular}




\begin{tabular}{|c|c|c|c|}
\hline $\begin{array}{c}\text { Parameter } \\
\text { Pengukuran }\end{array}$ & Poin Wawancara & Hasil & Poin \\
\hline & & $\begin{array}{l}\text { b. Penggunaan harga pasar } \\
\text { belum digunakan untuk kegiatan } \\
\text { sewa terutama TKD. }\end{array}$ & \\
\hline \multirow[t]{5}{*}{$\begin{array}{l}\text { Keterbukaan } \\
\text { informasi } \\
\text { kepada para } \\
\text { pemangku } \\
\text { kepentingan }\end{array}$} & $\begin{array}{l}\text { Bagaimana keterbukaan } \\
\text { informasi atas aset yang } \\
\text { selama ini dijalankan } \\
\text { (termasuk transaksi } \\
\text { pemeliharaan/pemanfaatan/ } \\
\text { penghapusan)? }\end{array}$ & $\begin{array}{l}\text { a. Informasi atas aset desa } \\
\text { yang diperoleh warga terbatas } \\
\text { pada saat pelaksanaan rapat } \\
\text { warga. } \\
\text { b. Informasi atas aset } \\
\text { belum dipublikasikan secara } \\
\text { luas. Informasi pemanfaatan aset } \\
\text { seperti case penyewaan TKD } \\
\text { belum sepenuhnya terbuka. }\end{array}$ & 0,40 \\
\hline & $\begin{array}{l}\text { Bagaimana kegiatan } \\
\text { pelaporan yang selama ini } \\
\text { dilakukan kepada pengambil } \\
\text { kebijakan? }\end{array}$ & $\begin{array}{l}\text { Pelaporan aset desa telah } \\
\text { dilakukan dan telah masuk } \\
\text { dalam Laporan Pelaksanaan } \\
\text { Pemerintahan Desa (LPPDes) } \\
\text { secara berkala dalam rangka } \\
\text { pengambilan kebijakan desa. }\end{array}$ & 1,00 \\
\hline & $\begin{array}{l}\text { Bagaimana kegiatan } \\
\text { pelaporan aset yang selama } \\
\text { ini dilakukan kepada } \\
\text { masyarakat? }\end{array}$ & $\begin{array}{l}\text { Informasi atas aset belum } \\
\text { dipublikasikan melalui kanal } \\
\text { media sosial dan website desa. } \\
\text { Inventarisasi aset belum } \\
\text { dipajang melalui papan } \\
\text { pengumuman di balai desa. } \\
\text { Perangkat desa hanya } \\
\text { menyatakan siap memberikan } \\
\text { data jika ada masyarakat yang } \\
\text { ingin akses terhadap data aset. }\end{array}$ & 0,40 \\
\hline & $\begin{array}{l}\text { Penggunaan pendapatan } \\
\text { dari aset }\end{array}$ & $\begin{array}{l}\text { Informasi penggunaan } \\
\text { pendapatan dari aset telah } \\
\text { tersedia namun belum } \\
\text { diungkapkan dengan lebih detil. }\end{array}$ & 0,60 \\
\hline & $\begin{array}{l}\text { Dampak penggunaan aset } \\
\text { kepada masyarakat jika } \\
\text { untuk tujuan sosial. }\end{array}$ & $\begin{array}{l}\text { Secara sosial, desa } \\
\text { memanfaatkan asetnya seperti: } \\
\text { a. TKD untuk lapangan } \\
\text { kegiaatan sepak bola } \\
\text { pemuda/warga; } \\
\text { b. Pondok Kesehatan Desa } \\
\text { (Ponkesdes) untuk menyediakan } \\
\text { akses kesehatan masyarakat } \\
\text { dengan Bidan dan Perawat Desa } \\
\text { stand-by selama Senin s.d. Sabtu; } \\
\text { c. Gedung di depan balai } \\
\text { desa dimanfaatkan untuk } \\
\text { kegiatan Posyandu balita dan }\end{array}$ & 1,00 \\
\hline
\end{tabular}




\begin{tabular}{|c|c|l|c|}
\hline $\begin{array}{c}\text { Parameter } \\
\text { Pengukuran }\end{array}$ & Poin Wawancara & \multicolumn{1}{|c|}{ Hasil } & Poin \\
\hline \multirow{2}{*}{ Score rata-rata } & $\begin{array}{l}\text { lansia dan bangunan untuk } \\
\text { PAUD; } \\
\text { d. Balai desa yang pada hari } \\
\text { Minggu dimanfaatkan sebagai } \\
\text { sanggar tari warga; } \\
\text { e. Ambulans desa beserta } \\
\text { sopir siap 24 jam. }\end{array}$ & \\
\hline
\end{tabular}

Sumber: Wawancara, diolah penulis

Hasil penelitian menunjukkan bahwa inventarisasi aset Desa Labruk Lor telah dilakukan dengan cukup baik. Namun kelemahan masih ditemukan pada kegiatan pemutakhiran data dimana pemutakhiran data aset desa baru dimulai pada tahun 2020. Proses inventarisasi dilakukan melalui aplikasi pengolah kata dan angka sederhana, kemudian mencetak label "invetaris desa/aset desa" untuk ditempel pada aset terkait. Klasifikasi atas aset desa juga belum terlihat dari dokumen inventaris aset desa. Secara umum tidak terdapat permasalahan dengan kepatuhan terhadap regulasi dalam pelaksanaan pengadaan, pemanfaatan, penjualan, dan penghapusan aset desa. Namun pihak desa belum menggunakan harga pasar terkini terkait dengan penentuan tarif pemanfaatan Tanah Kas Desa (TKD).

Aspek Keterbukaan Informasi menjadi hal yang perlu mendapatkan perhatian. Informasi aset desa telah disampaikan melalui forum musyawarah desa dan laporan LPPDes yang disusun secara berkala, namun belum dipublikasikan secara luas melalui kanal media sosial dan Website desa.

Melihat hal-hal tersebut, skor yang diberikan untuk benchmark ini adalah sebesar 0,636 (cukup) dari maksimal 1. Skor tersebut didapatkan dari rata-rata masing-masing poin wawancara terkait dengan aspek inventarisasi aset dasar dan keterbukaan informasi kepada para pemangku kepentingan.

\section{d. Pengukuran Kinerja Lanjutan Aset Desa Labruk Lor}

Indikator Dasar mengadopsi metode yang dikembangkan oleh Hariyono (2007), yang terdiri dari 4 (empat) indikator, yaitu kondisi fisik, penggunaan, pemanfaatan dan finansial. Penelitian ini mengevaluasi kinerja aset desa yang mempunyai nilai signifikan dan yang digunakan untuk mendukung penyelenggaraan tugas dan fungsi pemerintahan, diantaranya adalah: Tanah Kas Desa (TKD), gedung dan bangunan kompleks balai desa, kendaraan bermotor berupa ambulans desa dan sepeda motor operasional perangkat desa, serta peralatan dan mesin berupa komputer/laptop dan printer.

Berikut adalah hasil evaluasi Kinerja Lanjutan Aset Desa Labruk Lor:

\section{1) TKD (Tanah Kas Desa)}

Sejalan dengan Permendagri Nomor 1 Tahun 2016, TKD merupakan salah satu kekayaan asli desa. Desa Labruk Lor memiliki TKD seluas $101.660 \mathrm{~m}^{2}$. Tanah tersebut berupa hamparan sawah yang berlokasi tidak jauh dari kompleks balai Desa Labruk Lor. Menurut catatan yang berhasil dikumpulkan peneliti, aset ini diperoleh pada tahun 1970 tanpa ada rincian sumber dana ataupun sumber pembiayaan lainnya. Bukti kepemilikan aset ini masih berupa letter $C$ dan desa saat ini sedang mengupayakan sertifikasi, namun masih menunggu ketersediaan anggaran dari desa ataupun kabupaten. 
Tabel 3.2 Hasil Evaluasi Kinerja Lanjutan TKD Labruk Lor, Kab. Lumajang, Jawa Timur

\begin{tabular}{|c|c|c|c|}
\hline $\begin{array}{l}\text { Parameter } \\
\text { Pengukuran }\end{array}$ & Poin Wawancara dan Observasi & Hasil & Poin \\
\hline \multirow{3}{*}{ Kondisi Fisik } & $\begin{array}{l}\text { kesesuaian antara kondisi aset } \\
\text { secara fisik di lapangan dengan } \\
\text { catatan/register aset? }\end{array}$ & fisik dan catatan sama & 1,00 \\
\hline & kondisi aset di lapangan? & kondisi aset BAIK & 1,00 \\
\hline & $\begin{array}{l}\text { rencana kondisi aset masa depan } \\
\text { (rencana } \\
\text { perbaikan/pemeliharaan/perubahan } \\
\text { tujuan penggunaan)? }\end{array}$ & $\begin{array}{l}\text { rencana sertifikasi } \\
\text { kepemilikan atas nama } \\
\text { Pemerintah Desa Labruk } \\
\text { Lor }\end{array}$ & 0,70 \\
\hline Penggunaan & $\begin{array}{l}\text { Tidak dilakukan evaluasi karena aset } \\
\text { tidak digunakan untuk mendukung } \\
\text { tugas dan fungsi pemerintahan desa. }\end{array}$ & - & - \\
\hline \multirow{5}{*}{ Pemanfaatan } & $\begin{array}{l}\text { kondisi aset yang tidak digunakan } \\
\text { dalam rangka mendukung } \\
\text { penyelenggaraan pemerintah? Idle } \\
\text { atau used? }\end{array}$ & dimanfaatkan & 1,00 \\
\hline & $\begin{array}{l}\text { skema pemanfaatan aset } \\
\text { (sewa/pinjam pakai/kerja sama } \\
\text { pemanfaatan/ BGS/BSG)? }\end{array}$ & sewa menyewa & 1,00 \\
\hline & $\begin{array}{l}\text { kelengkapan surat perjanjian atas } \\
\text { aset yang dimanfaatkan? }\end{array}$ & $\begin{array}{l}\text { lengkap dikeola oleh } \\
\text { masing-masing } \\
\text { perangkat desa }\end{array}$ & 1,00 \\
\hline & $\begin{array}{l}\text { dampak sosial kepada warga } \\
\text { masyarakat atas aset yang } \\
\text { dimanfaatkan? }\end{array}$ & $\begin{array}{l}\text { Dampak kepada } \text { warga } \\
\text { belum optimal karena } \\
\text { sebagian besar hasil } \\
\text { pemanfaatan aset desa } \\
\text { dialokasikan untuk } \\
\text { memenuhi hak perangkat } \\
\text { desa. }\end{array}$ & 0,50 \\
\hline & $\begin{array}{l}\text { Bagaimana kontribusi pemanfaatan } \\
\text { aset desat terhadap pendapatan asli } \\
\text { desa? }\end{array}$ & $\begin{array}{l}\text { Hasil pemanfaatan aset } \\
\text { desa belum didasarkan } \\
\text { pada nilai wajar aset } \\
\text { sehingga penerimaan } \\
\text { desa tidak optimal. }\end{array}$ & 0,30 \\
\hline \multirow{3}{*}{ Finansial } & $\begin{array}{l}\text { realisasi biaya operasional aset } \\
\text { dibandingkan dengan } \\
\text { anggaran/target? }\end{array}$ & - & - \\
\hline & $\begin{array}{l}\text { realisasi biaya pemeliharaan aset } \\
\text { dibandingkan dengan } \\
\text { anggaran/target? }\end{array}$ & - & - \\
\hline & $\begin{array}{l}\text { realisasi biaya pengadaan aset } \\
\text { dibandingkan dengan } \\
\text { anggaran/target? }\end{array}$ & - & - \\
\hline
\end{tabular}




\begin{tabular}{|l|l|l|c|}
\hline $\begin{array}{c}\text { Parameter } \\
\text { Pengukuran }\end{array}$ & Poin Wawancara dan Observasi & Hasil & Poin \\
\hline & $\begin{array}{l}\text { realisasi Pendapatan Asli Desa dari } \\
\text { pemanfaatan aset dibandingkan } \\
\text { dengan anggaran/target? }\end{array}$ & $\begin{array}{l}\text { anggaran dan realisasi } \\
\text { sesuai }\end{array}$ & 1,00 \\
\cline { 2 - 4 } & $\begin{array}{l}\text { kewajaran nilai kontribusi terhadap } \\
\text { Pendapatan Asli Desa dari } \\
\text { pemanfaatan aset jika dibandingkan } \\
\text { dengan aset lain yang serupa? }\end{array}$ & $\begin{array}{l}\text { belum sesuai dengan } \\
\text { harga wajar }\end{array}$ & 0,30 \\
\cline { 2 - 4 } & $\begin{array}{l}\text { future cash flow yang diharapkan } \\
\text { diterima dari pemanfaatan aset? }\end{array}$ & $\begin{array}{l}\text { akses menuju lokasi aset } \\
\text { sedang diperbaiki, akan } \\
\text { menaikkan nilai aset }\end{array}$ & 0,80 \\
\hline \multicolumn{1}{|c|}{ Skor Rata-Rata } & $\mathbf{0 , 7 6 4}$ \\
\hline
\end{tabular}

Sumber: Wawancara dan Observasi, diolah Penulis

Hasil penelitian memberikan nilai 1 untuk Indikator Kondisi Fisik karena kondisi aset di lapangan telah sesuai dengan kondisi yang tercatat, yakni dalam kondisi baik. Penelitian ini tidak memberikan penilaian atas Indikator Penggunaan karena TKD desa Labruk Lor tidak digunakan untuk mendukung kegiatan pemerintahan. Penelitian ini belum memberikan nilai maksimal pada kinerja pemanfaatan aset desa karena hasil pemanfaatan aset yang belum optimal mengingat nilai yang digunakan sebagai dasar untuk menghitung nilai pemanfaatan belum menggunakan nilai wajar aset. Meski dari hasil pemanfaatan TKD belum memberikan kontribusi pendapatan yang optimal, penelitian menunjukkan bahwa nilai manfaat telah dirasakan masyarakat desa. Salah satu contohnya adalah dengan dilakukannya pemanfaatan TKD untuk lapangan sepak bola yang disambut antusias oleh warga.

Kinerja finansial belum mencapai nilai optimal karena tarif sewa TKD yang masih belum menggunakan nilai wajar aset yang berdampak pada tidak maksimalnya pendapatan yang diterima desa. Lebih lanjut, hasil sewa TKD belum memberikan dampak pada peningkatan Pendapatan Asli Desa karena dialokasikan untuk kegiatan pemerintahan desa.

Secara keseluruhan, rata-rata nilai kinerja aset desa Labruk Lor yang diperoleh dari 4 indikator lanjutan tersebut di atas adalah sebesar 0,764 dari maksimal 1 (cukup).

\section{2) Gedung dan Bangunan Kompleks Balai Desa}

Di atas kompleks Balai Desa Labruk Lor berdiri bangunan/gedung yang menjadi pusat pemerintahan Desa Labruk Lor. Sertifikat tanah kompleks diterbitkan Badan Pertanahan Kabupaten Lumajang, dengan luas total sebesar $876 \mathrm{~m}^{2}$. Aset ini telah dicatat pada catatan inventaris desa, dengan informasi waktu perolehan pada tahun 1970.

Tabel 3.3 Hasil Evaluasi Kinerja Aset Lanjutan atas Kompleks Balai Desa Labruk Lor, Kab. Lumajang, Jawa Timur

\begin{tabular}{|c|c|c|c|}
\hline $\begin{array}{c}\text { Parameter } \\
\text { Pengukuran }\end{array}$ & Poin Wawancara dan Observasi & Hasil & Poin \\
\hline Kondisi Fisik & $\begin{array}{l}\text { kesesuaian antara kondisi aset } \\
\text { secara fisik di lapangan dengan } \\
\text { catatan/register aset? }\end{array}$ & $\begin{array}{l}\text { kondisi fisik sesuai dengan } \\
\text { catatan, hanya saja terdapat } \\
\text { perbedaan antara catatan } \\
246 \mathrm{~m}^{2} \text { sedangkan di } \\
\text { sertifikat tertulis } 876 \mathrm{~m}^{2}\end{array}$ & 0,80 \\
\hline
\end{tabular}




\begin{tabular}{|c|c|c|c|}
\hline $\begin{array}{l}\text { Parameter } \\
\text { Pengukuran }\end{array}$ & Poin Wawancara dan Observasi & Hasil & Poin \\
\hline & kondisi aset di lapangan? & kondisi fisik BAIK & 1,00 \\
\hline & $\begin{array}{l}\text { rencana kondisi aset masa depan } \\
\text { (rencana } \\
\text { perbaikan/pemeliharaan/perubahan } \\
\text { tujuan penggunaan)? }\end{array}$ & $\begin{array}{l}\text { terdapat rencana renovasi } \\
\text { seperti untuk tempat parkir, } \\
\text { musola dan tempat agen BNI }\end{array}$ & 0,80 \\
\hline \multirow{4}{*}{ Penggunaan } & $\begin{array}{l}\text { langkah yang dilakukan untuk } \\
\text { memastikan aset digunakan dalam } \\
\text { rangka mendukung penyelenggaraan } \\
\text { pemerintah desa? }\end{array}$ & $\begin{array}{l}\text { layout gedung ditata dengan } \\
\text { baik dengan space terbatas } \\
\text { namun dapat menampung } \\
\text { seluruh fungsi } \\
\text { pemerintahan desa sehari- } \\
\text { hari }\end{array}$ & 0,90 \\
\hline & $\begin{array}{l}\text { kesesuaian antara penggunaan aset } \\
\text { dengan tujuan untuk mendukung } \\
\text { pelayanan publik? }\end{array}$ & sesuai & 0,90 \\
\hline & $\begin{array}{l}\text { langkah yang dilakukan untuk } \\
\text { memastikan penggunaan aset telah } \\
\text { bebas dari potensi sengketa dan } \\
\text { masalah? }\end{array}$ & $\begin{array}{l}\text { telah terbit sertifikat } \\
\text { kepemilikan atas nama } \\
\text { pemerintah desa Labruk } \\
\text { Lor }\end{array}$ & 1,00 \\
\hline & $\begin{array}{l}\text { aset digunakan untuk mendukung } \\
\text { penyelenggaraan pemerintah desa, } \\
\text { optimalisasi penggunaannya? }\end{array}$ & $\begin{array}{l}\text { luas tanah dan bangunan } \\
\text { tidak terlalu luas, dapat } \\
\text { dioptimalkan menjadi } \\
\text { partisi-partisi ruang layanan } \\
\text { untuk warga }\end{array}$ & 0,80 \\
\hline \multirow{5}{*}{ Pemanfaatan } & $\begin{array}{l}\text { kondisi aset yang tidak digunakan } \\
\text { dalam rangka mendukung } \\
\text { penyelenggaraan pemerintah? } \\
\text { Idleatau used? }\end{array}$ & $\begin{array}{lr}\text { aset juga } & \text { dimanfaatkan } \\
\text { untuk } & \text { kegiatan } \\
\text { warga/sosial: } & \text { Posyandu, } \\
\text { PAUD, Ponkesdes } & \end{array}$ & 0,80 \\
\hline & $\begin{array}{l}\text { skema pemanfaatan aset } \\
\text { (sewa/pinjam pakai/kerja sama } \\
\text { pemanfaatan/BGS/BSG)? }\end{array}$ & pinjam pakai & 1,00 \\
\hline & $\begin{array}{l}\text { kelengkapan surat perjanjian atas } \\
\text { aset yang dimanfaatkan? }\end{array}$ & $\begin{array}{l}\text { PAUD ada, posyandu dan } \\
\text { ponkesdes tidak ada }\end{array}$ & 0,50 \\
\hline & $\begin{array}{l}\text { dampak sosial kepada warga } \\
\text { masyarakat atas aset yang } \\
\text { dimanfaatkan? }\end{array}$ & sangat bermanfaat & 1,00 \\
\hline & $\begin{array}{l}\text { jika aset dimanfaatkan secara } \\
\text { komersial, kontribusinya terhadap } \\
\text { pendapatan asli desa? }\end{array}$ & - & - \\
\hline \multirow{2}{*}{ Finansial } & $\begin{array}{l}\text { realisasi biaya operasional aset } \\
\text { dibandingkan dengan } \\
\text { anggaran/target? }\end{array}$ & sesuai & 1,00 \\
\hline & $\begin{array}{l}\text { realisasi biaya pemeliharaan aset } \\
\text { dibandingkan dengan } \\
\text { anggaran/target? }\end{array}$ & sesuai & 1,00 \\
\hline
\end{tabular}




\begin{tabular}{|c|c|c|c|}
\hline $\begin{array}{l}\text { Parameter } \\
\text { Pengukuran }\end{array}$ & Poin Wawancara dan Observasi & Hasil & Poin \\
\hline & $\begin{array}{l}\text { realisasi biaya pengadaan aset } \\
\text { dibandingkan dengan } \\
\text { anggaran/target? }\end{array}$ & sesuai & 1,00 \\
\hline & $\begin{array}{l}\text { realisasi Pendapatan Asli Desa dari } \\
\text { pemanfaatan aset dibandingkan } \\
\text { dengan anggaran/target? }\end{array}$ & - & - \\
\hline & $\begin{array}{l}\text { kewajaran nilai kontribusi terhadap } \\
\text { Pendapatan Asli Desa dari } \\
\text { pemanfaatan aset jika dibandingkan } \\
\text { dengan aset lain yang serupa? }\end{array}$ & - & - \\
\hline & $\begin{array}{l}\text { future cash flow yang diharapkan } \\
\text { diterima dari pemanfaatan aset? }\end{array}$ & $\begin{array}{l}\text { skema pinjam pakai dapat } \\
\text { ditinjau ulang menjadi sewa } \\
\text { menyewa, terutama untuk } \\
\text { kegiatan Pendidikan PAUD } \\
\text { karena ada iuran dari wali } \\
\text { murid }\end{array}$ & 0,70 \\
\hline \multicolumn{3}{|c|}{ Skor Rata-Rata } & 0,869 \\
\hline
\end{tabular}

Sumber: Wawancara dan Observasi, diolah Penulis

Gedung dan bangunan yang berdiri di Kompleks Balai Desa dibangun dengan mengunakan dana yang bersumber dari Alokasi Dana Desa. Kompleks Balai Desa Labruk Lor terdiri dari bangunan Kantor Balai Desa, Ponkesdes, Ruang PKK dan Ruang Kepala Dusun, Ruang Kepala Desa, Ruang Sekdesa, Ruang Keuangan, Ruang Pendamping, Ruang Pelayanan dan Ruang Kaur, Gedung PAUD, Gedung Posyandu, mushola, lahan parkir, dan toilet.

Penelitian atas kondisi fisik aset yang berada di kompleks balai desa menunjukkan bahwa secara fisik, aset desa di kompleks tersebut dalam kondisi bagus. Balai Desa dan ruangan pelayanan terlihat baru selesai direnovasi. Informasi mengenai kondisi tersebut juga tertuang dalam catatan aset desa, yang artinya adalah catatan tersebut telah dilakukan pemutakhiran. Hal ini sangat krusial karena jika berbicara mengenai aset, maka catatan aset sebagai salah satu dasar dalam pengambilan keputusan harus selalu memberikan informasi yang paling mutakhir. Jika tidak, maka keputusan terkait aset tersebut akan salah dan mungkin akan menimbulkan biaya ekstra atau bahkan kerugian bagi institusi yang bersangkutan. Untuk itu, penelitian menyimpulkan bahwa ditinjau dari Indikator Penggunaan, hasil yang diperoleh adalah Bagus dengan pertimbangan bahwa kompleks balai desa telah digunakan penuh untuk mendukung kegiatan pemerintahan dan untuk pelayanan masyarakat desa.

Penelitian atas pemanfaatan aset desa yang berada di dalam kompleks Balai desa menunjukkan bahwa aset-aset dimaksud telah dimanfaatkan dengan cukup optimal, antara lain untuk tempat berlatih seni tari bagi warga, Ponkesdes, posyandu, PAUD dan BUMDesa. Fungsi aset desa sebagai salah satu motor pelayanan kepada masyarakat dapat dikatakan optimal, tidak ada aset yang dibiarkan menganggur dan tidak terawat. Hasil wawancara juga menunjukkan bahwa masyarakat cukup terinformasi kalau mereka dapat memanfaatkan aset desa ketika mereka membutuhkan dan dengan siapa mereka harus berkomunikasi saat hendak memanfaatkan aset desa. Dari hasil penelitian tersebut dapat disimpulkan bahwa Indikator Pemanfaatan memberikan nilai Baik.

Secara aspek finansial, operasional dan pemeliharaan aset telah diakomodasi dalam APBDes dan sesuai harga wajar. Dari sisi gedung dan bangunan yang dimanfaatkan, tidak ada 
aspek finansial yang terlibat karena skema yang digunakan adalah pinjam pakai dalam rangka pemberdayaan dan pelayanan masyarakat.

Dari keempat indikator kinerja aset lanjutan, diperoleh kesimpulan bahwa nilai kinerja atas aset Gedung dan Bangunan yang berdiri di atas kompleks Balai Desa adalah sebesar 0,869 yaitu baik, dari nilai maksimal 1.

\section{3) Kendaraan Bermotor}

Pemerintah Desa Labruk Lor memiliki aset berupa kendaraan bermotor diantaranya adalah satu unit mobil minibus Tahun 2017 yang difungsikan sebagai ambulans desa, 1 unit sepeda motor operasional tahun 2010 yang difungsikan sebagai kendaraan operasional kepala desa, dan 2 unit sepeda motor tahun 1990 yang difungsikan untuk kendaraan operasional sekretaris desa dan ketua BPD. Semua aset berupa kendaraan bermotor merupakan hibah dari Pemerintah Kabupaten Lumajang. Bukti kepemilikan berupa BPKB dan STNK lengkap dipegang oleh pemerintah desa.

Tabel 3.3 Evaluasi Kinerja Lanjutan Aset Kendaraan Bermotor Desa Labruk Lor, Kab. Lumajang, Jawa Timur

\begin{tabular}{|c|c|c|c|}
\hline $\begin{array}{l}\text { Parameter } \\
\text { Pengukuran }\end{array}$ & Poin Wawancara dan Observasi & Hasil & Poin \\
\hline \multirow{3}{*}{ Kondisi Fisik } & $\begin{array}{l}\text { kesesuaian antara kondisi aset } \\
\text { secara fisik di lapangan dengan } \\
\text { catatan/register aset? }\end{array}$ & $\begin{array}{l}\text { ambulans: sesuai, } \\
\text { sepeda motor: } 1 \text { rusak } \\
\text { disimpan di Gudang - tidak } \\
\text { sesuai, } 1 \text { dibawa kepala desa, } \\
1 \text { dibawa anggota BPD }\end{array}$ & 0,50 \\
\hline & kondisi aset di lapangan? & $\begin{array}{l}\text { ambulans: BAIK, } \\
\text { sepeda motor: } 1 \text { rusak } \\
\text { disimpan di Gudang, motor } \\
\text { operasional kepala desa dan } \\
\text { anggota BPD tidak dapat } \\
\text { diakses }\end{array}$ & 0,50 \\
\hline & $\begin{array}{l}\text { rencana kondisi aset masa depan } \\
\text { (rencana } \\
\text { perbaikan/pemeliharaan/perubahan } \\
\text { tujuan penggunaan)? }\end{array}$ & $\begin{array}{l}\text { belum ada rencana } \\
\text { perbaikan } \\
\text { rusak }\end{array}$ & 0,40 \\
\hline \multirow{3}{*}{ Penggunaan } & $\begin{array}{l}\text { langkah yang dilakukan untuk } \\
\text { memastikan aset digunakan dalam } \\
\text { rangka mendukung penyelenggaraan } \\
\text { pemerintah desa? }\end{array}$ & $\begin{array}{l}\text { hanya ambulans desa yang } \\
\text { digunakan dalam rangka } \\
\text { penyelenggaraan pelayanan }\end{array}$ & 0,60 \\
\hline & $\begin{array}{l}\text { kesesuaian antara penggunaan aset } \\
\text { dengan tujuan untuk mendukung } \\
\text { pelayanan publik? }\end{array}$ & $\begin{array}{l}\text { hanya ambulans desa yang } \\
\text { digunakan dalam rangka } \\
\text { penyelenggaraan } \\
\text { pelayanan }\end{array}$ & 0,60 \\
\hline & $\begin{array}{l}\text { langkah yang dilakukan untuk } \\
\text { memastikan penggunaan aset telah } \\
\text { bebas dari potensi sengketa dan } \\
\text { masalah? }\end{array}$ & $\begin{array}{l}\text { kelengkapan BPKB dan } \\
\text { STNK ada untuk masing- } \\
\text { masing aset }\end{array}$ & 1,00 \\
\hline
\end{tabular}




\begin{tabular}{|c|c|c|c|}
\hline $\begin{array}{l}\text { Parameter } \\
\text { Pengukuran }\end{array}$ & Poin Wawancara dan Observasi & Hasil & Poin \\
\hline & $\begin{array}{l}\text { aset digunakan untuk mendukung } \\
\text { penyelenggaraan pemerintah desa, } \\
\text { optimalisasi penggunaannya? }\end{array}$ & $\begin{array}{l}\text { belum optimal, kecuali } \\
\text { ambulans untuk melayani } \\
\text { kebutuhan warga }\end{array}$ & 0,60 \\
\hline Pemanfaatan & $\begin{array}{l}\text { Tidak dilakukan evaluasi karena aset } \\
\text { tidak dimanfaatkan selain untuk } \\
\text { mendukung tugas dan fungsi } \\
\text { pemerintahan desa. }\end{array}$ & - & - \\
\hline \multirow{6}{*}{ Finansial } & $\begin{array}{l}\text { realisasi biaya operasional aset } \\
\text { dibandingkan dengan } \\
\text { anggaran/target? }\end{array}$ & sesuai & 1.00 \\
\hline & $\begin{array}{l}\text { realisasi biaya pemeliharaan aset } \\
\text { dibandingkan dengan } \\
\text { anggaran/target? }\end{array}$ & sesuai & 1,00 \\
\hline & $\begin{array}{l}\text { realisasi biaya pengadaan aset } \\
\text { dibandingkan dengan } \\
\text { anggaran/target? }\end{array}$ & - & - \\
\hline & $\begin{array}{l}\text { realisasi Pendapatan Asli Desa dari } \\
\text { pemanfaatan aset dibandingkan } \\
\text { dengan anggaran/target? }\end{array}$ & - & - \\
\hline & $\begin{array}{l}\text { kewajaran nilai kontribusi terhadap } \\
\text { Pendapatan Asli Desa dari } \\
\text { pemanfaatan aset jika dibandingkan } \\
\text { dengan aset lain yang serupa? }\end{array}$ & - & - \\
\hline & $\begin{array}{l}\text { future cash flow yang diharapkan } \\
\text { diterima dari pemanfaatan aset? }\end{array}$ & - & - \\
\hline \multicolumn{3}{|c|}{ Skor Rata-Rata } & 0,689 \\
\hline
\end{tabular}

Sumber: Wawancara dan Observasi, diolah Penulis

Fisik mobil ambulans dalam kondisi baik dan kondisi ini telah tercatat dalam pembukuan aset desa. Sedangkan untuk aset berupa sepeda motor operasional berada dalam kondisi rusak berat dan belum ada rencana perbaikan. Lebih lanjut untuk sepeda motor operasional kepala desa dan kepala Badan Permusyawaratan Desa (BPD) tidak dapat diakses. Hal ini disebabkan pada saat penelitian berlangsung, kendaraan sepeda motor operasional kepala desa dan kepala BPD masing-masing sedang dibawa oleh keluarga kepala desa dan kepala BPD.

Ditinjau dari penggunaan aset, hanya ambulans yang digunakan untuk mendukung kegiatan pemerintahan dan layanan kesehatan warga. Kendaraan roda dua yang lain tidak dapat digunakan untuk pelayanan karena rusak sehingga hanya dibiarkan tersimpan di dalam Gudang. Lebih lanjut, pihak desa belum memiliki rencana untuk melakukan perbaikan atas aset tersebut. Penilaian atas indikator Pemanfaatan tidak dilakukan karena seluruh aset tidak sedang dimanfaatkan oleh pihak ketiga. Dari aspek finansial, hasil penelitian menunjukkan bahwa biaya operasional dan pemeliharaan aset dibebankan pada APBDes sesuai harga wajar yakni untuk aset berupa ambulans desa saja.

Dengan memperhatikan aspek-aspek di atas, penelitian menyimpulkan bahwa nilai kinerja lanjutan atas aset kendaraan bermotor Desa Labruk Lor adalah 0,689 (cukup) dari maksimal 1. 


\section{4) Laptop, Komputer dan Printer}

Laptop, computer dan printer merupakan aset penting dalam rangka penyediaan layanan pemerintahan desa serta dalam rangka mendukung tugas sehari-hari perangkat desa. Desa Labruk Lor memiliki enam unit komputer, empat unit laptop dan enam unit printer dari berbagai merk. Aset tersebut merupakan hasil pengadaan yang dilakukan dari tahun 2015 sampai 2018 yang bersumber dari dana Alokasi Dana Desa dan Bagi Hasil Pajak/Retribusi.

Tabel 3.4 Hasil Evaluasi Kinerja Aset Peralatan dan Mesin Desa Labruk Lor, Kab. Lumajang, Jawa Timur (Hariyono, 2007)

\begin{tabular}{|c|c|c|c|}
\hline $\begin{array}{c}\text { Parameter } \\
\text { Pengukuran }\end{array}$ & Poin Wawancara dan Observasi & Hasil & Poin \\
\hline \multirow{3}{*}{ Kondisi Fisik } & $\begin{array}{l}\text { kesesuaian antara kondisi aset } \\
\text { secara fisik di lapangan dengan } \\
\text { catatan/register aset? }\end{array}$ & $\begin{array}{l}\text { terdapat ketidaksesuaian } \\
\text { antara fisik dan catatan aset, } \\
\text { banyak aset rusak yang } \\
\text { belum tercatat }\end{array}$ & 0,50 \\
\hline & kondisi aset di lapangan? & $\begin{array}{l}\text { kondisi aset yang digunakan } \\
\text { untuk tugas sehari-hari baik, } \\
\text { kecuali yang dalam kondisi } \\
\text { rusak }\end{array}$ & 0,50 \\
\hline & $\begin{array}{l}\text { rencana kondisi aset masa depan } \\
\text { (rencana } \\
\text { perbaikan/pemeliharaan/perubahan } \\
\text { tujuan penggunaan)? }\end{array}$ & $\begin{array}{l}\text { pemeliharaan berkala terus } \\
\text { dilakukan, namun terhambat } \\
\text { refocusing anggaran terkait } \\
\text { pemulihan COVID-19 }\end{array}$ & 0,70 \\
\hline \multirow{4}{*}{ Penggunaan } & $\begin{array}{l}\text { langkah yang dilakukan untuk } \\
\text { memastikan aset digunakan dalam } \\
\text { rangka mendukung penyelenggaraan } \\
\text { pemerintah desa? }\end{array}$ & $\begin{array}{l}\text { aset berupa laptop, } \\
\text { computer dan printer secara } \\
\text { de facto memang digunakan } \\
\text { dalam rangka } \\
\text { penyelenggaraan } \\
\text { pemerintahan dan tugas } \\
\text { sehari-hari }\end{array}$ & 0,80 \\
\hline & $\begin{array}{l}\text { kesesuaian antara penggunaan aset } \\
\text { dengan tujuan untuk mendukung } \\
\text { pelayanan publik? }\end{array}$ & sesuai & 0,90 \\
\hline & $\begin{array}{l}\text { langkah yang dilakukan untuk } \\
\text { memastikan penggunaan aset telah } \\
\text { bebas dari potensi sengketa dan } \\
\text { masalah? }\end{array}$ & $\begin{array}{l}\text { pengamanan aset menjadi } \\
\text { tanggung jawab pribadi } \\
\text { masing-masing perangkat } \\
\text { desa, ada bukti pembelian } \\
\text { dan telah ada label } \\
\text { "inventaris desa" }\end{array}$ & 0,90 \\
\hline & $\begin{array}{l}\text { aset digunakan untuk mendukung } \\
\text { penyelenggaraan pemerintah desa, } \\
\text { optimalisasi penggunaannya? }\end{array}$ & $\begin{array}{l}\text { digunakan setiap hari secara } \\
\text { optimal }\end{array}$ & 1,00 \\
\hline Pemanfaatan & $\begin{array}{l}\text { Tidak dilakukan evaluasi karena aset } \\
\text { tidak dimanfaatkan selain untuk } \\
\text { mendukung tugas dan fungsi } \\
\text { pemerintahan desa. }\end{array}$ & & \\
\hline Finansial & $\begin{array}{l}\text { realisasi biaya operasional aset } \\
\text { dibandingkan dengan } \\
\text { anggaran/target? }\end{array}$ & sesuai & 1,00 \\
\hline
\end{tabular}




\begin{tabular}{|c|l|l|c|}
\hline $\begin{array}{c}\text { Parameter } \\
\text { Pengukuran }\end{array}$ & Poin Wawancara dan Observasi & Hasil & Poin \\
\hline \multirow{y}{*}{} & $\begin{array}{l}\text { realisasi biaya pemeliharaan aset } \\
\text { dibandingkan dengan } \\
\text { anggaran/target? }\end{array}$ & sesuai & 1,00 \\
\cline { 2 - 4 } & $\begin{array}{l}\text { realisasi biaya pengadaan aset } \\
\text { dibandingkan dengan } \\
\text { anggaran/target? }\end{array}$ & sesuai & 1,00 \\
\cline { 2 - 4 } & $\begin{array}{l}\text { realisasi Pendapatan Asli Desa dari } \\
\text { pemanfaatan aset dibandingkan } \\
\text { dengan anggaran/target? }\end{array}$ & & - \\
\cline { 2 - 4 } & $\begin{array}{l}\text { kewajaran nilai kontribusi terhadap } \\
\text { Pendapatan Asli Desa dari } \\
\text { pemanfaatan aset jika dibandingkan } \\
\text { dengan aset lain yang serupa? }\end{array}$ & & - \\
\cline { 2 - 5 } & $\begin{array}{l}\text { future cash flow yang diharapkan } \\
\text { diterima dari pemanfaatan aset? }\end{array}$ & & $\mathbf{0 , 8 2}$ \\
\hline
\end{tabular}

Sumber: Wawancara dan Observasi, diolah Penulis

Sebagian aset dalam kondisi baik dan tercatat dalam laporan aset. Sebagian lain dalam kondisi rusak dan sebagian lainnya tidak diketahui kondisinya karena tidak tercatat.

Dari sisi penggunaan, penelitian menyimpulkan bahwa aset yang berada dalam kondisi baik benar-benar digunakan untuk menunjang kegiatan pemerintahan dan pekerjaan sehari-sehari perangkat desa. Sedangkan aset yang tidak digunakan, berada dalam kondisi rusak, tidak ditemukan dan tidak tercatat.

Penilaian atas indikator Pemanfaatan tidak dilakukan karena seluruh aset tidak sedang dimanfaatkan oleh pihak ketiga. Dari aspek finansial, hasil penelitian menunjukkan bahwa biaya operasional dan pemeliharaan aset dibebankan pada APBDes sesuai harga wajar.

Dengan memperhatikan aspek-aspek di atas, penelitian menyimpulkan bahwa nilai kinerja lanjutan atas aset kendaraan bermotor Desa Labruk Lor adalah 0,82 (baik) dari maksimal 1.

\section{5) Pemanfaatan Aset Desa Labruk Lor}

Tujuan utama dari pengelolaan aset desa adalah terselenggaranya pemerintahan desa dan terwujudnya pelayanan publik di desa. Selain itu, terdapat beberapa aset desa yang tidak digunakan dalam rangka tugas dan fungsi, sehingga dapat dimanfaatkan. Wawancara yang dilakukan kepada HA (wawancara, 8 Juni 2020) mengatakan bahwa beberapa aset desa dimanfaatkan oleh pihak ketiga dengan tujuan pemberdayaan masyarakat desa.

Tabel 3.5 Daftar Aset Desa Labruk Lor yang Dilakukan Pemanfaatan

\begin{tabular}{|c|l|l|l|l|}
\hline No & \multicolumn{1}{|c|}{ Aset Desa } & \multicolumn{1}{|c|}{$\begin{array}{c}\text { Skema } \\
\text { Pemanfaatan }\end{array}$} & \multicolumn{1}{|c|}{ Pemanfaat } & $\begin{array}{c}\text { Tujuan / Kegiatan } \\
\text { Pemanfaatan }\end{array}$ \\
\hline 1 & $\begin{array}{l}\text { Tanah Kas } \\
\text { Desa/TKD }\end{array}$ & $\begin{array}{l}\text { Sewa, Kelola } \\
\text { Mandiri }\end{array}$ & Perangkat Desa & $\begin{array}{l}\text { Tambahan Tunjangan } \\
\text { Perangkat Desa }\end{array}$ \\
\hline 2 & Balai Desa & Pinjam Pakai & Pegiat Tari Desa & $\begin{array}{l}\text { Pemberdayaan } \\
\text { Kegiatan Seni Tari }\end{array}$ \\
\hline
\end{tabular}


74 | Bina Ekonomi

\begin{tabular}{|c|l|l|l|l|}
3 & $\begin{array}{l}\text { Ponkesdes dan } \\
\text { Posyandu }\end{array}$ & Pinjam Pakai & $\begin{array}{l}\text { Bidan dan Perawat } \\
\text { Desa }\end{array}$ & $\begin{array}{l}\text { Pelayanan Kesehatan } \\
\text { Warga Desa }\end{array}$ \\
\hline 4 & Gedung PAUD & Pinjam Pakai & PAUD Amanah & $\begin{array}{l}\text { Pelayanan Pendidikan } \\
\text { Prasekolah }\end{array}$ \\
\hline 5 & $\begin{array}{l}\text { TKD 1 Hektar Hak } \\
\text { Kepala Desa }\end{array}$ & Tukar Pinjam & Warga Desa & $\begin{array}{l}\text { Lapangan Bola - } \\
\text { Kegiatan Sepak Bola } \\
\text { Pemuda Desa }\end{array}$ \\
\hline
\end{tabular}

Sumber: Diolah Penulis

\section{SIMPULAN, KETERBATASAN DAN IMPLIKASI}

Dari pembahasan yang telah disampaikan dalam bagian-bagian sebelumnya, dapat diambil kesimpulan bahwa evaluasi terhadap kinerja dasar aset Desa Labruk Lor memperoleh nilai 0,636 (Cukup). Sedangkan pengukuran kinerja lanjutan aset Desa Labruk Lor dilakukan sesuai dengan jenis aset yang dimiliki desa, rerata nilai mencapai 0,785 (baik), dengan rincian: aset berupa tanah TKD mendapat poin 0,764 (Cukup), Gedung dan Bangunan Kompleks Balai Desa 0,869 (Baik), Kendaraan Bermotor 0,689 (Cukup), Peralatan dan Mesin berupa Laptop, Komputer dan Laptop 0,82 (Baik). Optimalisasi aset Desa Labruk Lor berupa tanah TKD dilakukan melalui sewa, tukar pinjam TKD untuk lapangan sepak bola, balai desa untuk kegiatan latihan tari, Ponkesdes untuk pelayanan kesehatan warga, Posyandu, dan PAUD. Hasil yang diperoleh dari pemanfaatan/optimalisasi aset desa saat ini masih sepenuhnya digunakan untuk membayar tunjangan. Figur kepala desa menjadi kunci keberhasilan entitas desa untuk dapat mengelola asetnya dengan baik, selain itu pihak pemerintah desa diharapkan untuk dapat terus menjaga compliance terhadap regulasi, koordinasi dan mempertahankan hal-hal baik yang telah dicapai.

\section{DAFTAR PUSTAKA}

DJKN. (2020, June 18). BMN Idle, Kriteria dan Perlakuannya. Retrieved from www.djkn.kemenkeu.go.id: $\quad$ https://www.djkn.kemenkeu.go.id/kpknlcirebon/baca-artikel/13198/BMN-Idle-Kriteria-dan-Perlakuannya.html

Haas, R., Falls, L. C., \& Tighe, S. (2003). Performance Indicators for Properly Functioning Aset Management Systems. Australian Road Research Board, National Academy Standard, 19.

Hanis, M. H., Trigunarsyah, B., \& Connie, S. (2011). The application of public aset management in Indonesian local government: a case study in South Sulawesi Province. Journal of Corporate Real Estate .

Hariyono, A. (2007). Prinsip dan Teknik Manajemen Kekayaan Negara. Jakarta: Pusdiklat Keuangan Umum Department Keuangan RI.

Hwang, J., \& Chansik, L. (2018). Level of Service-based Performance Measurement of Aset Management of Public Office Buildings. KSCE Journal of Civil Engineering, 22(12), 4732 - 4783.

Jooste, J. (2003). A Performance Management Model For Physical Asset Management. Stellenbosch: University of Stellenbosch.

Kaganova, O., \& Nayyar - Stone, R. (2000). Municipal real property asset management: An overview of world experience, trends and financial implications. Journal of Real Estate Portfolio Management, 6(4), 307 - 326. 
Kaganova, O., \& Telgarsky, J. (2018). Management of capital asets by local governments: An assessment and benchmarking survey. International Journal of Strategic Property Management, 22(2), 143 - 156.

Puspitarini, I., \& Akhmadi, M. H. (2019). Measuring Public Aset Performance Using OutputBased Approach: Evidence From Indonesia. Journal of the Malaysia Institute of Planners .

Riratanaphong, C., \& Voordt, T. J. (2015). Public Real Estate Performance Measurement: A case study of a Bangkok Government Complex. JARS, 12(1).

Setiyono, N., Nurdin, D., \& Karim, M. Y. (2018, January 1). Analisis Kinerja Barang Milik Negara Berupa Aset Tanah dan Bangunan Pada Badan Layanan Umum universitas Tadulako. 76e Jurnal Katalogis, 6, 75-86.

Sugiyono. (2019). Metode Penelitian Kuantitatif, Kualitatif, dan R\&D. Bandung: Alfabeta. 